ОРГАНІЗАЦІЯ НАУКОВО-ДОСЛІДНИЦЬКОЇ ДІЯЛЬНОСТІ МАЙБУТНІХ ДИПЛОМАТІВ У ПРОЦЕСІ ПРОФЕСІЙНОЇ ПІДГОТОВКИ

\title{
ORGANIZATION OF RESEARCH ACTIVITIES OF FUTURE DIPLOMATS IN THE PROCESS OF PROFESSIONAL TRAINING
}

у статті розглянуто особливості організації науково-дослідницької діяльності майбутніх дипломатів у процесі профресійної підготовки.

Особистість фрахівия в галузі міжнародних відносин повинна вирізняти чіткість цілей і соціально значущих ціннісних орієнтацій, творче ставлення до справи, прагнення до високої продуктивності праці, до безперервного саморозвитку. Це висуває нові підвищені вимоги до знань майбутніх дипломатів, їх творчого розвитку, уміння знаходити найраціональніші конструктивні, технологічні, організаційні $\breve{~}$ економічні рішення, а також добре орієнтуватися у відборі наукової інформації та вирішувати різноманітні, принципово нові завдання. Виконання поставлених завдань щодо підготовки дипломатичних кадрів можливе лише в разі надання майбутнім дипломатам новітніх знань у галузі наукових досліджень. Це зобов'язує вищу школу широко залучати слухачів до науково-дослідницької діяльності. Для підготовки дипломатів че має принципове значення, оскільки професійна компетентність дипломатів визначається здатністю до вияву творчої активності від задуму, ідеї, плану до конкретного їх втілення в життя. Важливою умовою творчості є сприйняття нових ідей, здатність знаходити й порушувати проблеми, незалежність суджень і водночас уміння поступатися в наукових дискусіях.

Участь у науково-дослідницькій діяльності розвиває в майбутніх дипломатів рефлексію власних життєвих і професійних потреб та інтересів, яка здійснюється в процесі просресійно зорієнтованих дослідницьких завдань, що забезпечує об'єктивність і фрормує критичне й конструктивне ставлення до себе, допомагає усвідомити свою відповідність вимогам профессії та науково-дослідницькій діяльності, коли майбутній дипломат набуває навичок самостійного осмислення, знаходить сенс і шляхи вдосконалення себе в цій діяльності. Дослідницька діяльність задовольняє потреби майбутнього дипломата в досягненні успіху, самопізнанні, самореалізації, в розумінні змісту своєї діяльності, у системному баченні своїх перспектив.

Науково-дослідницька діяльність майбутнього дипломата $є$ важливою умовою розвитку творчого, ініціативного фрахівця 3 орієнтацією на постійне пізнання, прагнення до визначення сутності будь-якого явища, пошук найкращих засобів розв'язання професійних проблем, постійне експериментування, самоаналіз і самооцінку. Об'єктивна реальність спонукає приділяти більше уваги розвиткові дослідницьких умінь у майбутніх дипломатів.
Ключові слова: дослідницька діяльність, науково-дослідницька діяльність, майбутній дипломат, професійна підготовка.

The article considers the peculiarities of the organization of research activities of future diplomats in the process of professional training. The personality of a specialist in the field of international relations must distinguish between clear goals and socially significant value orientations, a creative attitude to work the desire for high productivity, for continuous selfdevelopment. This places new and increased demands on the knowledge of future diplomats, their creative development, the ability to find the most rational design, technological, organizational and economic solutions, as well as well-versed in the selection of scientific information and solve various, fundamentally new problems. Fulfillment of the set tasks regarding the training of diplomatic personnel is possible only in the case of providing future diplomats with the latest knowledge in the field of scientific research. This obliges the high school to involve students extensively in research activities. For the training of diplomats, this is of fundamental importance, because the professional competence of diplomats is determined by the ability to show creative activity from the idea, plan to their concrete implementation. An importan condition for creativity is the perception of new ideas, the ability to find and raise problems, the independence of judgments and at the same time the ability to yield in scientific discussions. Participation in research activities develops in future diplomats a reflection of their own life and professional needs and interests, which is carried out in the process of professionally oriented research tasks, which provides objectivity and forms a critical and constructive attitude to themselves, helps to realize their compliance with the profession, research activities, when the future diplomat acquires the skills of independent thinking, finds meaning and ways to improve themselves in this activity.

Research activity satisfies the needs of the future diplomat in achieving success, self-knowledge, self-realization, in understanding the content of their activities, in a systematic vision of their prospects.

The research activity of the future diplomat is an important condition for the development of a creative, proactive specialist with a focus on constant knowledge, the desire to determine the essence of any phenomenon, finding the best means of solving professional problems, constant experimentation, self-analysis and self-evaluation. Objective reality encourages us to pay more attention to the development of research skills in future diplomats.

Key words: research activity, future diplomat professional training.
Постановка проблеми в загальному вигляді та її зв'язок із важливими науковими чи практичними завданнями. 3 розвитком гуманістичної парадигми освіти актуалізувалися завдання фрор- мування активної, творчої особистості. Фундаментальна гуманістична база дає змогу на сучасному етапі розвитку суспільства визначити актуальні проблеми формування професійно компетентної 
особистості майбутнього дипломата в єдиному світовому освітньому просторі $з$ гуманістичних позицій: розвиток, співробітництво, самоосвіта, готовність пов'язувати свою професійну кар'єру 3 продовженням освіти, самопізнання, ціннісне розуміння світу й себе, духовність тощо.

Мета сучасної вищої школи української дипломатії - не тільки підготувати срахівця в певній ссрері діяльності або управління. Йдеться про фрормування дипломата, як особи, здатної до різнобічної ефрективної діяльності та самовдосконалення впродовж усього життя, як особи всебічно розвиненої, цивілізованої, високоосвіченої та високоорганізованої $[10$, с. 17]. Особистість фрахівця в галузі міжнародних відносин повинна вирізняти чіткість цілей і соціально значущих ціннісних орієнтацій, творче ставлення до справи, прагненням до високої продуктивності праці, до безперервного саморозвитку [5, с. 15].

Із прийняттям Закону України «Про вищу освіту» змінюється місія науково-дослідницької діяльності в університетах, посилюється роль досліджень у підготовці майбутніх фрахівців. Тобто, на зміну знаннєвій парадигмі підготовки здобувачів вищої освіти приходить навчання через дослідження [3].

Виконання поставлених завдань, щодо підготовки дипломатичних кадрів XXI століття, можливе лише у разі надання майбутнім дипломатам новітніх знань у галузі наукових досліджень. Це зобов'язує вищу школу широко залучати слухачів до науково-дослідної діяльності.

Аналіз останніх досліджень і публікацій. У сучасній вищій школі науково-дослідницька робота студентів завжди розглядалася як найбільш ефективний метод професійної підготовки, а тому вона стала предметом дослідження багатьох науковців, зокрема В. Загвязінського, М. Князян, О. Крушельницької, О. Микитюк.

Окремі аспекти організації науково-дослідницької діяльності майбутнього дипломата у процесі профресійної підготовки розкриваються у працях М. Клепар, М Мальського, Ю. Мороз, В. Ціватого та ін. Однак, зауважимо, що дослідження, які стосуються питань організації науково-дослідної діяльності майбутнього дипломата мають фррагментарний характер.

Виділення не вирішених раніше частин загальної проблеми. Системі профеесійної підготовки майбутніх дипломатів не вистачає різнорівневості, мобільності, гнучкості, безперервності, наступності, варіативності. Під час підготовки майбутніх дипломатів і фахівців-міжнародників до роботи за кордоном необхідно акцентувати на їх творчому розвитку, умінню знаходити найраціональніші конструктивні, технологічні, організаційні і економічні рішення, а також добре орієнтуватися у відборі наукової інсрормації та вирішувати різноманітні, принципово нові завдання [10, с. 23]. Це зумовлює нове бачення цілей професійної під- готовки майбутніх дипломатів, зміну ії статусу, посилення ролі науково-дослідницької діяльності у системі профресійної освіти.

Мета статті - розкрити особливості організації науково-дослідницької діяльності майбутнього дипломата у процесі профресійної підготовки.

Виклад основного матеріалу дослідження. Для з'ясування змісту категорії «дослідницька діяльність» доцільно розглянути її складові частини «дослідження» та «діяльність» і на основі ïx аналізу синтезувати інтегральне поняття «дослідницька діяльність». У педагогічному словнику діяльність визначається як «спосіб буття людини у світі, здатність її вносити в дійсність зміни. Основні компоненти діяльності: суб'єкт 3 його потребами; мета, відповідно до якої перетворюється предмет в об'єкт, на який спрямовано діяльність; засіб реалізації мети; результат діяльності. Загальним засобом діяльності $€$ сукупність знарядь праці, створених людьми, - техніка й технологія. Універсальним предметом діяльності $€$ природа й суспільство, а її загальним наслідком - олюднена природа» [2, с. 98].

Діяльність - процес активної взаємодії суб'єкта зі світом, під час якого суб'єкт задовольняє деякі свої потреби, діяльність характеризує свідому сторону особистості. Дослідження визначається як процес виробництва нових наукових знань, один 3 видів пізнавальної діяльності, як «процес і результат наукової діяльності, спрямованої на одержання суспільно значущих нових знань про закономірності, структуру, механізми фрункціонування явища, що вивчається, про зміст, принципи, методи й організаційні фрорми діяльності» [9, с. 516].

Саме дослідницький характер діяльності привчає майбутнього дипломата до самостійності, виховує вимогливість до себе, розвиває вміння аналізувати та синтезувати процеси і явища, що відбуваються у суспільстві, він сприяє фрормуванню відповідного складу мислення та активізує пошукову активність.

Дослідницьку роботу студентів можна умовно класифікувати за різними принципами: місця і часу організації (позааудиторна, аудиторна); кількості учасників (індивідуальні, колективні, групові); об'єкту дослідження і рівня новизни (науководослідна і навчально-дослідна) [1, с. 83].

Зазначимо, що визначені види дослідницької діяльності мають умовний характер, оскільки вони знаходяться у стані взаємодії, взаємодоповнення та взаємозбагачення.

Сутність науково-дослідницької діяльності як специорічного виду людської діяльності, характеризується фрактором «відкриття» нового знання, яке виникає на основі колишніх знань і досвіду людини, великої уваги у цьому аспекті надається процесу пізнання, який Ю. Пассов розглядає як «основу, що породжує пізнавальну активність студента і викладача» [8, с. 11]. 
В Енциклопедії освіти науково-дослідна робота студентів визначається як «важлива складова частина навчального процесу, органічна складова частина освіти, базовий елемент і рушійна сила її розвитку» [4, с. 554].

Більшість науковців пов'язують термін «науково-дослідна діяльність» із терміном «творчість». Так, В. Лазарєв і Н. Ставринова про зв'язок творчості і дослідницької роботи говорять таке: творча діяльність переходить у дослідницьку щоразу, коли фрахівець, узагальнюючи свій досвід, впроваджуючи досвід своїх колег або нові технології, свідомо використовує такі методи дослідження, які дають можливість отримати об'єктивні дані про результати його творчої роботи [7, с. 51].

Творчість студента є однією із найважливіших умов становлення майбутнього фахівця. Студент високого рівня розвитку творчості відчуває внутрішню потребу у дослідницькій діяльності. Необхідно зазначити, що творчість має у своїй основі два взаємопов'язаних початки: особистісний та діяльнісний, які можуть розвиватися тільки один через одного. Тому творчість може розглядатися як внутрішня сутнісна властивість діяльності особистості, що виявляється як у діяльності взагалі, так і в конкретних фрормах. Такою конкретною фрормою діяльності і є дослідницька діяльність людини [1, с. 148].

Для підготовки дипломатів це має принципове значення, оскільки професійна компетентність дипломатів визначається здатністю до вияву творчої активності від задуму, ідеї, плану до конкретного їх втілення у життя. Важливою умовою творчості є сприйняття нових ідей, здатності знаходити й порушувати проблеми, незалежність суджень і водночас уміння поступатися у наукових дискусіях. Отже, для розвитку творчого потенціалу майбутніх дипломатів, необхідно в освітньому процесі використовувати завдання дослідницького характеру, які сприяють розвитку продуктивного мислення та творчої активності, набуттю навичок самостійного пошуку рішень, самоорганізації.

Науково-дослідна робота може здійснюватися в межах студентського наукового товариства, наукового або предметного гуртків, наукового семінару, науково-практичної конфреренції, магістерського проєкту.

Основними формами науково-дослідної роботи студентів є: діагностика - збір і узагальнення емпіричних даних, які характеризують стан об'єкта, що вивчається; створення концепції - виклад і обґрунтування власного розуміння проблеми і шляхи її розв'язання; експериментально-дослідна перевірка істинності висунутої гіпотези.

Цінним у контексті нашого дослідження є досвід науково-дослідницької підготовки в Дипломатичній академії при Міністерстві закордонних справ (далі - МЗС) України, яку було створено 30 травня
1995 р., з метою підготовки керівних дипломатичних кадрів та магістрів зовнішньої політики для роботи у сорері міжнародних відносин [10, с. 5].

Науково-дослідницька підготовка в Академії один із пріоритетних напрямів магістерської програми навчання. Важливим етапом у підготовці дипломатів було включення до освітнього процесу Дипломатичної академії науково-практичного семінару «Методологія та організація наукових досліджень». Ця навчальна дисципліна дозволяє майбутнім дипломатам освоїти елементи методики і організації наукових досліджень, що багато в чому сприяє розвитку їх раціонального творчого мислення, організації оптимальної розумової діяльності [10, с. 24].

У період навчання в Дипломатичній академії при МЗС України слухачам створювалися умови для збору матеріалів і підготовки текстів дисертаційних досліджень, забезпечувалося наукове керівництво й надавалася підтримка на етапі захисту кандидатської дисертації.

Слухачі Академії брали активну участь у міжнародних науково-практичних конореренціях, симпозіумах, конгресах, круглих столах. Також здобувачі наукових ступенів мали нагоду публікувати результати своїх досліджень у «Науковому віснику Дипломатичній академії України», затвердженому Вищою атестаційною комісією України, як спеціалізоване фрахове видання з історичних, політичних і юридичних наук.

Окремої уваги в контексті порушеної проблеми заслуговує досвід Львівського національного університету імені Івана Франка, у якому в 1992 р. було відкрито фракультет міжнародних відносин. Однією 3 провідних кафедр фракультету стала кафедра міжнародних відносин і країнознавства (3 2001 р. - кафредра міжнародних відносин і дипломатичної служби) [6, с. 3].

Важливим напрямом роботи кафедри завжди було проведення наукових конореренцій з актуальних проблем міжнародних відносин та зовнішньої політики України, передусім - студентських наукових конференцій, семінарів і «круглих столів» з участю колег із багатьох університетів України та європейських країн. Організатором таких конфреренцій і «круглих столів» найчастіше виступає створений ще 1995 р. Центр «Молода дипломатія», діяльність якого спрямована на поглиблення та розширення як теоретичних знань, так і практичних навичок роботи у міжнародному середовищі. Цій же меті підпорядкована й практика стажування студентів у Міністерстві закордонних справ України, комітетах Верховної Ради України, Представництві Міністерства закордонних справ України у Львові, управліннях міжнародних зв'язків обласної та міської державних адміністрацій, посольствах і консульствах України за кордоном. Частина студентів має змогу поглиблювати свої знання в уні- 
верситетах США, Великої Британії, Німеччини, Австрії, Польщі, Швеції, Канади, інших країн, а також у численних літніх школах за кордоном.

Поруч із виконанням основного завдання - підготовки фрахівців у галузі міжнародних відносин кафредра наполегливо працює над нарощуванням свого наукового потенціалу, готуючи молодих викладачів, кадри вищої кваліфрікації.

Так, у 2004 р. було створено Спеціалізовану Вчену раду з захисту кандидатських дисертацій зі спеціальності «Політичні проблеми міжнародних систем та глобального розвитку». 3 того часу в Раді захищено чимала кількість дисертацій, переважно випускниками кафедри, які відтепер на більш високому рівні продовжують свою наукову та викладацьку діяльність. Удосконалення підготовки фрахівців у галузі міжнародних відносин залишається першочерговим пріоритетом кафедри [6, с. 7].

Орієнтація науково-дослідної роботи на особистість студента, поєднання в їі змісті диференційованих та індивідуальних завдань, побудованих на принципі альтернативних і варіаційних рішень, є важливою умовою, що забезпечує високий рівень інтересу до науково-дослідної роботи. Поступове поглиблення і ускладнення завдань дає можливість студентам перейти на вищий рівень пізнавальної діяльності [1, с. 149].

Участь у дослідницькій діяльності розвиває у майбутніх дипломатів рефлексія власних життєвих і професійних потреб та інтересів, яка здійснюється у процесі профресійно зорієнтованих дослідницьких завдань, що забезпечує об'єктивність та формує критичне і конструктивне ставлення до себе, допомагає усвідомити свою відповідність вимогам профресії та науково-дослідницькій діяльності, коли майбутній дипломат набуває навичок самостійного осмислення, знаходить сенс і шляхи удосконалення себе у цій діяльності. Дослідницька діяльність задовольняє потреби майбутнього дипломата у досягненні успіху, самопізнанні, самореалізації, в розумінні змісту своєї діяльності, у системному баченні своїх перспектив.

Висновки. Отже, науково-дослідницька діяльність майбутнього дипломата $є$ важливою умовою розвитку творчого, ініціативного фрахівця з орієнтацією на постійне пізнання, прагнення до визначення сутності будь-якого явища, пошуку найкращих засобів розв'язання професійних проблем, постійного експериментування, самоаналізу й самооцінки. Об'єктивна реальність спонукає приділяти більше уваги розвиткові дослідницьких умінь у майбутніх дипломатів.

\section{БІБЛІОГРАФІЧНИЙ СПИСОК:}

1. Вечірко М.С. Формування готовності майбутніх вчителів фрілологічних спеціальностей до професійного самовизначення : дис. ... канд. пед.. наук : 13.00.04. Кіровоград, 2013. 231 с.

2. Гончаренко С.У. Український педагогічний словник. Київ : Либідь, 1997. 376 с.

3. Закон України «Про вищу освіту»: чинне законодавство : (офріц. текст). Київ : Паливода А.В., 2014. $100 \mathrm{c}$

4. Енциклопедія освіти / Акад. пед. наук України ; Головний редактор В.Г. Кремень. Київ : Юрінком Інтер, 2008. 1040 c.

5. Ермошин Ю.А. Обучение специалистов в области международных отношений профессиональному дискурсу (жанр официальных публичных выступлений) : дисс. ... канд. пед. наук : 13.00.02. Москва, 2010. 229 с. URL: https://www.dissercat.com/ content/obuchenie-spetsialistov-v-oblastimezhdunarodnykh-otnoshenii-professionalnomudiskursu.

6. Мальський М.М., Мороз Ю.М. Підготовка фрахівців міжнародників в умовах трансформації міжнародної системи. Вісник Львівського університету. Серія: Міжнародні відносини. 2012. Вип. 30. С. 3-8.

7. Лазарев В.С., Ставринова Н.Н. Критерии и уровни готовности будущего педагога к исследовательской деятельности. Педагогика. 2006. № 2. C. 51-59.

8. Пассов Е.И. Культуросообразная модель просрессиональной подготовки учителя: фрилософрия, содержание, реализация. Іноземні мови. 2002. № 4. С. 3-19.

9. Советский энциклопедический словарь. Изд. 4-е. Москва : Советская энциклопедия, 1987. 1600 с.

10. Ціватий В.Г. Дипломатія і підготовка дипломата XXI століття: традиції, інновації, моделі. Науковий вісник Дипломатичної академії України. 2004. Вип. 10 (1). С. 11-31. 